\title{
DISCREPANCY ANALYSIS OF AUTHENTIC ASSESSMENT IMPLEMENTATION BASED ON THE CURRICULUM 2013 IN EFL CLASSROOM AT SMA NEGERI 1 KUTA UTARA, BADUNG
}

\author{
N. L. P. Suastini ${ }^{1}$, A. A. I. N. Marhaeni ${ }^{1}$, L. P. Artini ${ }^{2}$ \\ ${ }^{123}$ English Language Education, Post Graduate Program, Universitas Pendidikan Ganesha, Singaraja \\ e-mail: putu.suastini@pasca.undiksha.ac.id, marhaeni@pasca.undiksha.ac.id, \\ artini@pasca.undiksha.ac.id
}

This study aimed at analyzing the discrepancy between the ideal authentic assessment implementation and the real implementation in a Senior High School EFL class at senior, and describing the teachers' belief on authentic assessment. The study was conducted in SMAN 1 Kuta Utara, Badung. There are two research questions which become guidelines of this study: a) the extent of the discrepancy of authentic assessment implementation in EFL classroom of SMAN 1 Kuta Utara based on Curriculum2013; b) the EFL teachers' belief on the authentic assessment based on Curriculum 2013. The research employed Discrepancy Evaluation Model by Provus modified by Marhaeni (2012). The data were collected through observation sheet, questionnaire and interview. The obtained data were analyzed using descriptive statistics of Ideal Theoretical Reference. The research found that in self-assessment, the discrepancy was big (77,22\%); in performance assessment, the discrepancy was kecil $(10.04 \%)$;in project assessment, the discrepancy was very big (5.5\%), and in portfolio assessment, the discrepancy was big (66.26\%). In general it can be concluded that the discrepancy in authentic assessment implementation in EFL classroom at SMAN 1 Kuta Utara was categorized as moderate $(46.19 \%)$. In contrast with the finding of discrepancy of authentic assessment, the finding in teachers' belief is positive $(65.56 \%)$. These findings indicate that teachers' belief are positive toward authentic assessment but they did not optimally implement authentic assessment.

\section{Keywords: authentic assessment, discrepancy, teachers' belief.}

\section{INTRODUCTION}

The development of science and technology brings big changes in all aspects of life. The changes can be seen in the way how people run their lives. Everything becomes fast and simple. However, the development forces people to compete more tightly to be able to survive in life. People have to be able to struggle in their lives. The ability of struggling should be prepared since their early education. Therefore, education becomes the starting point in order to be able to face the world.

Indonesia has done many effort to develop curriculum which is aimed at answering the world need, that is, to prepare the young generation with some competencies as what are implied at the four pillars of learning. Those are (1) competence in collecting, selecting, processing and managing information, (2) competence in mastering instruments of knowing and understanding, (3) competence in effectively communicating with others, (4) competence in adapting oneself to changes in life, (5) competence in cooperatively working in team, and (6) competence in resolving conflict through peaceful dialogue and negotiation. Curriculum's objectives incorporate the principle of learning throughout life. Subject matter content is no longer organized on basis of individual discipline but more in an interdisciplinary or integrated approach. Learning outcomes are not expressed merely in test score but in terms of knowledge, skills, values, or competencies as embedded in the pillars of learning.

Considering those explanations, the learning outcomes can be seen from skills, values or competencies which are hard to use test- traditional test, as the instrument to measure learner competencies. Authentic assessment is the most suggested assessment used to measure learner outcome. Curriculum 2013 as the newest curriculum applies authentic assessment as the way to assess learning outcome. The purpose of Curriculum 2013 is to 
prepare Indonesian people who are creative, innovative, and productive with good characters, to be able to contribute in social life well (Permendikbud No. 70/2013). The authentic assessment is an assessment requiring students to use the same competencies or combination of knowledge, skill, and attitudes that they need to apply in the criterion situation in professional life (Lombardi, in Retnawati, 2016).

In implementing a new curriculum, there are several challenges that the government might encounter. Eraslan (2013) examined the reflection of Turkish Mathematics teachers on the implementation of the new curriculum for grade 6-8 in a pilot school. From the interviews and observations, he found that teachers were in favor of the new Mathematics curriculum; however, they mention a lack of initial training and asked for an ongoing in-service training at the school level. They need training, supervision and supports to enhance the quality of teaching and learning(Sofyan, 2013; Farida, 2013; Makeleny \& Sethusa, 2014).

There are four types of authentic assessment according to Permendikbud no 53 year 2015. They are (1) Self-assessment, (2) Project assessment, (3) Performance assessment, and (4) Portfolio assessment. Among those four assessments, performance assessment is the most used, especially in EFL School. The phenomena can be seen in the researcher school. The school applied Curriculum 2013 for one semester. The teachers (EFL teachers) applied performance assessment mostly. The way how they planned, executed, analyzed and reported the assessment was not as what was implied in the curriculum.

By knowing the fact of the implementation of authentic assessment, the researcher tried to figure out the discrepancy of Curriculum 2013, as the standard, and the implementation, as the observed. Here also, the researcher tried to observed the teachers' belief whether it affects the discrepancy or not. Therefore, to make the study reaches the goals, the researcher conducted this research in Kuta Utara District, particularly at SMA Negeri 1 Kuta Utara as the piloting school in applying Curriculum 2013.

\section{Statement of the Problem}

Based on the real situation happened and what the government expected, in this study the researcher states the research questions as follow:

1. To what extent is the discrepancy between the established standard of authentic assessment implementation required by Curriculum 2013 and the practice in EFL classroom of SMAN 1 Kuta Utara?

2. What is the teacher's beliefs of the authentic assessment based on Curriculum 2013 in SMAN 1 Kuta Utara?

\section{Purpose of the Study}

To find out to what extent the discrepancy between the implementation of the authentic assessment and the standard based on Curriculum in EFL classroom in SMAN 1 Kuta Utara is and the teacher's beliefs on the authentic assessment in SMAN 1 Kuta Utara based on Curriculum 2013.

\section{Scope of the Study}

Based on the background of the study, the scopes of the study are as follows:

1. The present study is concerned with the discrepancy between the established standard of authentic assessment implementation required by Curriculum 2013 and the practice in EFL classroom of SMAN 1 Kuta Utara and the teacher's beliefs of the authentic assessment based on Curriculum 2013 in SMAN 1 Kuta Utara

2. The Subject of the study are the the English teachers at SMAN 1 Kuta Utara

\section{RESEARCH METHOD}

The study was descriptive qualitative The purpose of the study was to find out to what extent the discrepancy between the implementation of the authentic assessment and the standard based on Curriculum in EFL classroom in SMAN 1 Kuta Utara is and the teacher's 
beliefs on the authentic assessment in SMAN 1 Kuta Utara based on Curriculum 2013 by using Ideal Theoretic Reference Criteria

\section{Research Subject}

The subjects of this study were the English teachers at SMAN 1 Kuta Utara, Badung. The object of the study here was the way how the teachers implemented the authentic assessment which covers planning, executing and analyzing and reporting. It also investigated the teacher's beliefs toward the authentic assessment which could affect the way how the teacher implements the authentic assessment in classroom.

\section{Research Instruments}

In completing the data, the researcher used qualitative data consists of observation sheets, questionnaire and interview

a. Observation sheets

In this study, a non-participant observation technique was implemented. Here, the data were recorded in the research localities using observation sheets which constituted a scientific record.

b. Questionnaire

The questionnaire that was utilized to collect data on teacher's beliefs was originally developed by Marhaeni (2013). This questionnaire was intended to gather information how teacher emotionally respond to the implementation of the authentic assessment.

c. Interview guide

This instrument was to ensure that the researcher did not miss the important issues. The format of this instrument was semi-structured interview. The questions were formulated by the researcher in the interview setting.

\section{Research Design}

This study implemented Provus' discrepancy model which had been simplified by Marhaeni (2012). There are five stages that were recommended as the result of the simplification. Those are: (1) Design development. In this stage, the researcher prepared the equipment needed in the evaluation process and also formulating the measurable standards in planning, executing, analyzing and reporting. The instruments of the evaluation are also prepared by the researcher. The instruments used are validated by three judges. The researcher plans how the data are gathered. (2) Installation evaluation, this stage is the stage of designing the standard program that is compared to the beginning program. This stage is to find out whether the program had already implemented or not. In this stage, the researcher does the observation by him or herself. (3) Process evaluation. It is the process of collecting data to find out that the program run well. Then, find out the impact or the effect of the program. (4) Objective evaluation stage. Collecting data and analyzing the data is used to find out the achievement degree, and (5) Comparison stage. Here, the researcher compared the real situation of the EFL teachers in implementing the authentic assessment to the standard based on Curriculum 2013. Therefore, the discrepancy was found.

\section{Procedure of Data Collection}

The methods of data collection were; document study, observation, and interview (table/ matric). The data were collected from the planning, executing, analyzing and reporting stages. The procedures of the study was divided into three steps; 1) Planning; prepared the blue print of the three steps of authentic assessment implementations then, made the instruments, then validating process, 2) Data Collection; did classroom observation, interview for the missing data and giving questionnaire to know the teacher's beliefs, and 3) Reporting; The data got from the observation sheets and the questionnaire was recapitulated by using ldeal Theoretic Reference Criteria. The results were presented in the form of tables and histograms. 


\section{Data Analysis}

In this study, the data were analyzed by descriptive qualitative method. To describe the extent of discrepancy between standard and observed, the data were analyzed using Ideal Theoretic Reference Criteria with five scales. . More specifically, the technique used was Ideal Theoretical Reference with five scales to analyze the data gained from the observation sheet and the data from the questionnaire distribution to determine the category of teacher's beliefs towards authentic assessment implementation. In more details, the stages of data analysis in this study were presented as follows: First, determining the Ideal Theoretical Reference. Therefore, two stages were conducted: (1). calculating the value of Mi and SDi; (2) constructing the Ideal Theoretical Reference by referring to the value of Mi and Sdi. (3) calculating the obtained score of Authentic assessment implementation/ stages of implementation; (4) determining the discrepancy occurred by referring to the Ideal Theoretical Reference of each authentic assessment; (5) calculating the percentile of the discrepancy; (6) calculating the discrepancy by calculating the subtraction of the standard (in this study is presented by $100 \%$ ) with the observed percentile.

In conclusion, the data gathered from the document study and observation which involved planning, executing, and analyzing and reporting stage was analyzed by using Ideal Theoretical Reference Criteria. Moreover, all the data gathered was used to figure out the discrepancy of authentic assessment implementation that had been conducted by the EFL teachers in SMAN 1 Kuta Utara.

\section{FINDING AND DISCUSSION Findings on the discrepancy}

The study found that, the discrepancy on authentic assessment implementation in EFL class at school observed was very big. The overall result of the discrepancy rate was $75.39 \%$ (big) with $80.00 \%$ (very big) occurred at the planning stage, $66.16 \%$ ( big) at execution stage, $80.00 \%$ ( very big) at analysis and reporting stage. This finding indicated that there was a discrepancy between the standard of authentic assessment in Curriculum 2013 and the real implementation.

\section{Findings on the teacher's beliefs}

From the nine items responded by the teachers, it was found that the teachers' belief on authentic assessment was categorized as moderate. The overall result of was found positive $(157.33$ or $65.56 \%)$. They did not implement all of the authentic assessment as what were stated on the curriculum it was due to have lack of knowledge how to implement them, especially self-assessment well. They also said that they did not belief in the students responds. However, they had a good curiosity to learn about the authentic assessment further.

\section{Discussions}

The discussion is divided into two topic of discussion which stated in the research questions of this study. First, it is about the discrepancy occurred between the implementation of the authentic assessment in EFL classroom in SMAN 1 Kuta Utara and the standard stated in Curriculum 2013. Second, it is the teacher's beliefs toward the authentic assessment based on the Curriculum 2013.

At SMAN 1 Kuta Utara, there are two of four of the authentic assessment implemented quite well. They are performance assessment and project assessment as the most preferable assessments. The discrepancy occurred in performance assessment is $10.04 \%$ (small) and $5.5 \%$ (very small) for project assessment. The information got from the interview showed that the teacher found that they could assess the students easily by using those assessments. They did not need much time and energy to do it. In using the rubric of assessment, they also found not too challenging. They know what to assess and how to give the students score. The activities done by the teachers had fulfilled the criteria mentioned by Herrington \& Herrinton in Retnawati, (2016). They said that there are four criteria that will be used in the authentic assessment; (1) context, (2) problem-solving skills, higher order thinking and production of knowledge, (3) task factor which stimulates a wide range of active responses, and (4) 
indicators which provide multiple indicators of learning, achieves validity and reliability. These criteria were added by Darling-Hemond (2013) with the fifth criterion was the use of valid, reliable, and fair assessment.

The widest discrepancy happened at SMAN 1 Kuta Utara was in self-assessment implementation. The discrepancy was $77.22 \%$ (big). From the document, the data found that the teacher did not plan the assessment as they did not have a form model of self-assessment which led them to make the instrument well. The lack of knowledge made them reluctant to do the assessment. Other factor which influenced the discrepancy is the teacher did not belief in the student ability to do self-assessment. They thought that it was enough to learn about the student by observation. This idea was on the contrast with Coleman et al (2011). Coleman et al said authentic assessment "needs to support learning in general and be driven by the learner, to foster the attributes we expect of graduates and help learners prepare for a lifetime of learning". It was also not in a line with Curriculum 2013 which stated Learner's selfassessment offers opportunities for the students to have self-regulate learning, and the responsibility in appraising his or her own progress. An important aspect of providing students with authentic context where learning can take place is to intrinsically link the content to be learnt with the assessment in a meaningful way. Self-assessment will focus student attention on the objectives of learning and provides teachers with information they would otherwise lack (Marhaeni, 2012).

Portfolio assessment implementation as the second biggest discrepancy occurred at SMAN 1 Kuta Utara almost had the same case with self-assessment implementation. The teachers did not plan the assessment well. They collected the students works without any folders and the works did not show the 'history' of the students' development. The teachers only took their first works then corrected the works without asking them to submit the correct ones. The discrepancy was $66.26 \%$ (big). From the three teachers only one of them collected the students' works. She collected them and gave feedback on them but the collection was not in a folder. The works were also not so complete, only some of them were kept as the teacher thought they were necessary. When the researcher asked whether she discussed it with the owner, she said, 'yes, sometimes'. Other teachers said that they never collect students' works. After they give mark to the works, they would return them to the students. It was on the contrary with Popham (1995) who said that portfolio assessment is as an assessment approach centered on the systematic appraisal of a student's collected work samples. This means that the teacher systematically collects pieces of each student's work including rough drafts and final drafts. This allows teachers to assess the student's progress from the place they were at in the beginning of the lesson and where they fall after the lesson is completed.

From the explanation above, it can be seen that there are many factors influence the implementation of authentic assessment like the basic training teachers received, lack of curriculum interpretation, inadequate resources, poor infrastructure, and overcrowding (Makeleny et al., 2014). They found that the basic training affected teachers' knowledge and understanding of curriculum principles, instructional planning, teaching and learning, and assessment practices in that some teachers were unable to meet the requirements of curriculum implementation.

The teacher as the transmitter of knowledge will bring 'something' while he or she is doing his or her job. Those can be experiences, and background knowledge. These factors will form a belief. Generally, beliefs are formed through personal experiences and interactions in daily life and interpretations of events individuals have engaged in (Al-Sharafi, 1998; see Hsieh, 2002). In educational contexts, this concept of belief system governs teaching behaviors, with individual pedagogies reflecting a teacher's beliefs about language teaching (Bauch, 1984). Teachers' thought processes and instructional decisions are influenced by their beliefs (Borg, 1999). These beliefs largely direct teachers' choices and practices, such as addressing teaching objectives, designing lessons, selecting tasks and activities, and assessing student performances (Brown, 2003).

The teacher's beliefs about authentic assessment in SMAN 1 Kuta Utara was categorizes positive. There were nine items being questioned to the teachers; mastery learning, assessment authenticity, teacher's understanding toward authentic assessment, 
assessment continuity, curriculum expectation, society expectation towards English mastery for senior high school level, school's vision and mission, student's participation in assessment and teacher's expectation toward authentic assessment. In mastery learning, the teachers had a very positive beliefs. They understood and agreed that the implementation of authentic assessment must be based on Curriculum 2013. Assessment authenticity effected students' ability, especially in writing (Sudira, 2010).

\section{CONCLUSION AND SUGGESTIONS}

Authentic assessment as the trending topic in the implementation of Curriculum 2013 makes the teachers got frustrated in the real implementation. There were some reasons stated by the teacher but the most crucial one is they have lack of knowledge and 'picture' about the assessment. As what was happened in SMAN 1 Kuta Utara, the teachers did not implement all type of the authentic assessments as what Curriculum 2013 expected. When they did the assessment, they sometimes did it as their ways, therefore, there are some discrepancies found in their practices.

The discrepancy found in every type of assessment and in every grade. In Selfassessment the discrepancy found was very wide in all grades as the teachers did not implement it. They thought that this kind of assessment was less reliable. The same thing happened to Portfolio assessment. The teacher did not carry out this assessment, they felt that this assessment was too tiring, and they did not plan it, too.

Teacher's perception or teacher's beliefs on authentic assessment is one of the factors which influence the implementation of the authentic assessment. There is a tight correlation among experiences, attitudes, intentions, and action which form a belief. Generally, beliefs are formed through personal experiences and interactions in daily life and interpretations of events individuals have engaged in (Al-Sharafi, 1998; see Hsieh, 2002).

\section{REFERENCES}

Aliningsih, Fitri and Sofwan, Ahmad. (2013). English teachers' perception and practices of authentic assessment. Language Circle: Journal of Language and Literature,10(1). Available online at http://journal.unnes.ac.id e-ISSN 2460-853X

Bauch, P.(1984). The impact of teachers' instructional beliefs on their teaching: Implications for research and practice. ERIC Digest. ED252954

Black, P., \& Wiliam, D.(1998). Assessment and classroom learning. Educational Assessment: Principles, Policy and Practice, 5(1), 7-74.

Borg, S.(1999). Teachers' theories in grammar teaching. ELT Journal, 53(3), 157-167.

Brookhart, S.(2013). Educational assessment knowledge and skills for teachers, educational measurement: Issues and Practice, 30, 3-12

Brown, G., T. L. (2002). Teachers' conceptions of assessment (Unpublished doctoral dissertation). University of Auckland, New Zealand.

Brown, G. T. L. (2003). Teachers' instructional conceptions: Assessment's relationship to learning, teaching, curriculum, and teacher efficacy. Paper presented at the Joint Conference of the Australian and New Zealand Associations for Research in Education, Auckland, New Zealand.

Boud, D. (1995). Enhancing learning through self-assessment. London: Kogan Page

Callison, D.(1998). Authentic assessment in school library media activities monthly. Bloomington.

Cheng, M.(1997). The impacts of teachers' beliefs on students' anxiety about foreign language learning. The proceedings of the Sixth International Symposium on English Teaching (pp. 113-129). Taipei: Crane. 
Cheung, D.(2000). Measuring teachers' meta-orientations to curriculum: Application of hierarchical confirmatory analysis. Journal of Experimental Education, 68(2), 149-165.

Cimer SO. 2011. The effect of portfolios on students' learning: student teachers' views. European Journal of Teacher Education 34(2) 161-176

Cody, W.S. (1996). Six steps to Design, Implement, and Assess. Ode States.

Coleman,K.S.,Rourke,A.J.(2011). Authentic assessment in learning; Reflective \& Collaborative Writing in The Arts. Ascilite. 2011. Australia

Croasmun, J. T. L. (20011). Using Likert-Type Scale in The Social Sciences. Jornal of Adult Education,40(1), 2011. Montain Plains Adult Education Ascociation(Pp. 119).

Darling-Hammond, L.H1994). Performance-based assessment and educational equity. Harvard Educational Review 53 (1), 5-30

Daniel, L., Stufflebeam, G. F., Madause, \& Kellaghan, T. (Eds.). (2002). Evaluation models. Viewpoints on education and services evaluation second edition. Kluwer Academic Publishers. USA

Delandshere, G., \& Jones, J. H. (1999). Elementary teachers'beliefs about assessment in mathematics: A case of assessment paralysis. Journal of Curriculum and Supervision, 14(3), 216-240.

Emzir. (2012). Metodologi penelitian pendidikan: Kuantitatif dan Kualitatif. Jakarta: Raja Grafindo Persada

Eraslan,A. (2013). Teachers' reflections on the implementation of the new elementary school mathematics curriculum in Turkey. HU Journal of Education, 28(2), 152-165.

Gulikers, J., Bastiaens, Th. \& Kirschner, P. (2004). A Five-dimensional framework for authentic assessment : Educational Technology Research and Development, 52(3), 6785.

Gregory, R. J. (2000). The psychological testing. history, principle and applications. Wheaton Colleges, Wheaton, Illinois.

Hanna,G.S., \& Dettmer,P.A. (2004). Assessment for effective teaching: Using contextadaptive planning.Boston: Pearson Education, Inc.

Henri J, Frewer R, Amato A, Thilakaratne R, Trinidad S. (2004). Changing practice: An exercise in curriculum development of innovative teaching in construction technology. In $R$. Atkinson, C. McBeath, D. Jonas-Dwyer \& R. Phillips (Eds), Beyond the comfort zone: Proceedings of the 21st ASCILITE Conference. Perth, 5-8 December: 365-373.

Horwitz, E. (1988). The beliefs about language learning of beginning university foreign language students. The Modern Language Journal, 72, 283-294.

Hsieh, H. (2002). Teachers' beliefs about English learning: A case study of elementary school English teachers in Taipei County. Unpublished Master Thesis. Taipei: National Taipei Teachers' College.

Joice,C.,Spiller, L., Twist, J.,(2008). Self-assessment: What teachers think. New Zealand Council for Education Research. Wellington

Kankam, B., Bordoh, A., Ehsun, I., Bassaw,T.K., Korang, F.Y.(2014). Teachers' perception of Authentic Assessment Techniques Practice in Social Studies Lesson in Senior High Schools in Ghana. International Journal of Education Research and Information Science. 1(4), 62-68.

Kaufman, J.C., Plucker, J.A., Baer, J. (2008). Essentials of creativity assessment. Hoboken N.Y.: Wiley

Kurniati, I. \& Sani, B. (2014). Sukses mengimplementasikan kurikulum 2013. Jakarta: Kata Pena. 
Kementrian Pendidikan dan Kebudayaan. (2015). Bahan uji publik kurikulu Republik Indonesia. Kementrian Pendidikan dan Kebudayaan.

Kementrian Agama Direktorat Pendidikan Madrasah, Direktorat Jendral Pendidikan Islam. (2014). Pedoman Penilaian Hasil Belajar Peserta Didik Tingkat Madrasah Aliyah (MA).

Kingsland A J. (1996). Time Expenditure, Workload, and Student Satisfaction in ProblemBased Learning. In Wilkerson, L. \& Gijselaer, W. H. (Eds.) Bringing Problem-based Learning to Higher Education: Theory and Practice. San Francisco: Josey-Bass

Kusnandar. (2013). Penilaian autentik: Penilaian Hasil Belajar Peserta Didik Berdasarkan Kurikulum 2013. Jakarta: PT Raja Grafindo Persada

Kurebwa, M.W. \& Nyaruwata, L.T.(2013). Assessment challenges in the primary schools: A Case of Gweru Urban Schools. Greener journal of Education Research, 3(7),336-344.

Lam R, Lee I. (2010). Balancing the dual functions of portfolio assessment. ELT Journal 64:1, 54-64

Light G, Cox R.( 2001). Learning and teaching in higher education' London: Sage

Lodico, M., Spaulding, D. \& Voegtle, K. (2006). Method in educational research: From Theory to Practice. San Francisco: Jossey-Bass

Lumadi, M.M.(2013). Challenges besetting teachers in classroom assessment: an exploratory perspective. Journal of Social Science, 34(3), 211-221.

Makeleny, N. T \& Sethusha, M. J.(2014). The experiences of foundation phase teachers in implementing curriculum. Mediterranian Journal of Social Sciences. MCSER Publishing, Rome-Italy.

Marhaeni, A.A.I.N.(2005). Pengaruh assessment portfolio dan motivasi berprestasi dalam belajar bahasa inggris terhadap kemampuan menulis dalam bahasa inggris. Unpublished Dessertation: Proram Pascasarjana Universitas Negeri Jakarta

Marhaeni. A.A.I.N.(2012). Evaluasi program pendidikan; Buku Ajar Mahasiswa Program Pasca Sarjana. Singaraja. Ganesha University. Singaraja

Marhaeni, A. A. I. N.(2013). Authenticity of English made assessment. Proceedings. Konferensi HEPI , 20-22 September 2013di Manado (pp. 333-317).

Marhaeni, A.A.I.N., Dantes,N.,Artini,LP.(2013). Pengembangan prangkat asesmen otentik sebagai asesmen proses dan produk dalam implementasi KTSP mapel B. Inggris di SMP Prov. Bali. Ganesha University.

Marhaeni,A.A.I.Aand Artini,L.P (2015). Asesmen autentik dan pendidikan bermakna: Implementasi Kurikulum 2013

Marhaeni, A.A.I.N, Dantes, N., \& Artini,L.P.(2014). Pengembangan perangkat pembelajaran asesmen otentik sebagai asesment proses dan produk dalam implementasi KTSP mapel Bahasa Inggris di SMP Prov Bali. Undiksha Singaraja.

McDonald B. (2011). Portfolio assessment: direct from the classroom. Assessment and Evaluation in Higher Education 23 February (iFirst)

Munoz, Patricia A., Palacio, Marcela., \& Escobar, Liliana.(2012). Teachers' beliefs about assessment in an EFL context in Colombia. Universidad Nacional de Colombia, Facultad de Ciencias Humanas, Departamento de Lenguas Extranjeras. Profile 14(1), 143-158.April 2012. ISSN 1657-0790. Bogotá, Colombia.

Nitko, A.J. (1996). Educational assessment of students. (2 ${ }^{\text {nd }}$ ed). New Jersey: Merrill 
O'Sullivan AJ, Harris P, Hughes CS, Toohey SM, Balasooriya C, Velan G, Kumar RK, McNeil HP.( 2011). Linking assessment to undergraduate student capabilities through portfolio examination. Assessment and Evaluation in Higher Education 18 March (iFirst)

Permendikbud no 70/ 2013. Kerangka Dasar dan struktur kurikulum sekolah menengah kejuruan/ madrasah aliyah kejuruan.

Permendikbud no 64/2013. Standar isi pendidikan dasar dan menengah.

Permendikbud no 66/2013. Standar penilaian.

Permendikbud no 81a/2013. Implementasi kurikulum.

Permendikbud no 103/ 2014. Pembelajaran pada pendidikan dasar dan pendidikan menengah.

Permendikbud no 53/ 2015. Penilaian hasil belajar oleh pendidik dan satuan pendidikan pada pendidikan dasar dan pendidikan menengah.

Popham, W.J. (1995). Classroom assessment, what teachers need to know. Boston:Allyn and Bacon

Poskitt, J. and Taylor, K. (2008b). National Education Findings of Assess to Learn (AtoL) Report. Wellington: Ministry of Education. Retrieved 1 December 2008 from http://www.educationcounts.govt.nz/publications/schooling/27968/27984

Retnawati,H.,Hadi,S.,Nugraha,A.C..(2016).Vocational high school teachers' difficulties in implementing the assessment in Curriculum 2013 in Yogyakarta Province of Indonesia. Journal 9(1)

Rios, F. (1996). Teacher thinking in cultural contexts. New York: State University of New York Press.

Rueda, R., \& Garcia, E. (1994). Teachers' beliefs about reading assessment with Latino language minority students. Center for Research on Education, Diversity \& Excellence. NCRCDSLL Research Reports. Berkeley, CA: University of California.

Sarjana,P.(2010). Evaluasi pelaksanaan rintisan sekolah kategori mandiri(SKM) pada SMA Negeri 1 Tejakula tahun pelajaran 2009-2010. Journal Undiksha.

Segers M, Gijbels D, Thurlings M. (2008). The relationship between students' perceptions of portfolio assessment practice and their approaches to learning. Educational Studies 34(1), 35-44

Sofyan. Faridah.(2013). Dampak implementasi Kurikulum 2013 terhadap guru. Info Singkat 5(19).

Subandi. (2011). Deskripsi kualitatif sebagai satu metode dalam penelitian pertunjukan. Harmoni. 11(2).

Sudira, I Gede.(2010). Pengaruh asesmen kinerja dan kreatifitas siswa terhadap kemampuan menulis dalam mapel Bahasa Inggris (an Experimental study). Journal Pasca Sarjana. Undiksha.

Sugiyono. (2012). Metode penelitian pendidikan (Pendekatan Kuantitatif, Kualitatif, dan R\&D). Bandung: Alfabeta.

Tisani N. (2008). Challenges in producing a portfolio for assessment: in search of underpinning educational theories. Teaching in Higher Education 13(5), 549-557

UU no 20 / 2003. The National Education System.

Wijayanti, Dian Kadek.(2011). Pengaruh implementasi asesmen portofolio terhadap kemampuan menulis Bahasa Inggris ditinjau dari kecemasan siswa. (an experimental study). Journal Pasca Sarjana. Undiksha. 
Woods, D.(1996). Teacher cognition in language teaching. Cambridge: Cambridge University Press.

Zhou, Nanzhao and Sun Yunxiao. (2001). Toward learning society: Building Four Pillars of Learning. Beijing: Beijing Press 